\title{
Eosinophilic bodies in pyloric and Brunner's gland cells
}

\author{
C A Rubio, T Hirota, M Itabashi, B Jacobsson, H Lignelid
}

\begin{abstract}
A previously unreported cell phenotype occurred in the pyloric and Brunner glands in two gastrectomy specimens. The cells were characterised by homogeneous, eosinophilic material in the cytoplasm. The eosinophilic material had an abnormally strong reactivity for Cystatin $\mathrm{C}$, a protein found recently in the normal secretion of pyloric and Brunner's gland cells. The reason for the apparent cytoplasmic accumulation of cystatin $C$ in the two patients described remains unclear.
\end{abstract}

Department of

Pathology, National

(f Clin Pathol 1992;45:1119-1120)

Cancer Center

Research Institute,

Tokyo, Japan

C A Rubio

T Hirota

M Itabashi

Department of

Clinical Chemistry

and Pathology,

Danderyd Hospital,

Danderyd, Sweden

B Jacobsson

H Lignelid

Correspondence to:

Dr C A Rubio,

Department of Pathology

Karolinska Institute,

Stockholm, Sweden

Accepted for publication 13 July 1992

\section{Case report}

According to published findings ${ }^{1-4}$ pyloric glands and Brunner's glands in the duodenum are composed of a similar type of mucous secreting cell. Their nuclei are flattened against the basal aspect of the cells, the cytoplasm being filled with a large number of mucous droplets. ${ }^{4}$ Others have described pyloric cells as having poorly defined borders and a bubbly cytoplasm. $^{23}$

While reviewing gastrectomy specimens from Japanese patients, we noticed cystically dilated pyloric glands, lined by mucous secreting cells with eosinophilic bodies in their

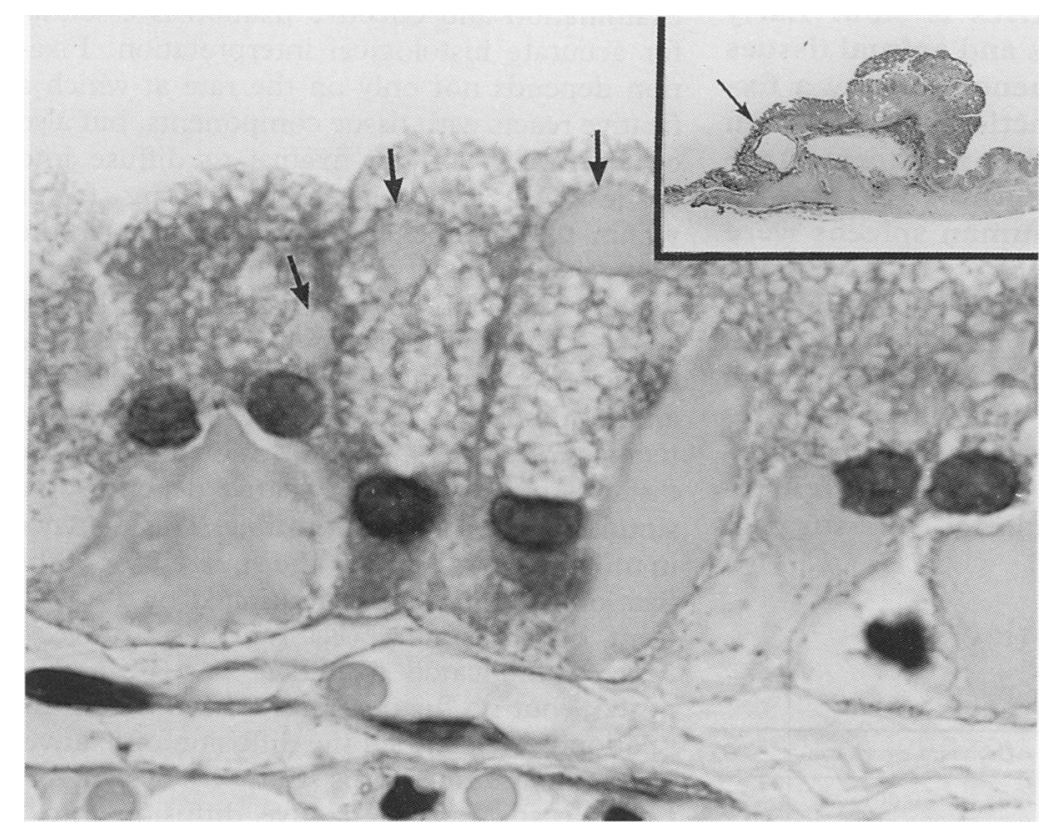

Figure 1 Duodenal (Brunner's) gland cyst lined by cells containing intracytoplasmic eosinophilic homogenous material. Note remnant mucin (arrows) in the apical aspect of the cells (alcian blue $(p H 2 \cdot 5)$ periodic acid Schiff). Insert: low power view of the area. cytoplasm in one specimen and cystically dilated Brunner's gland lined by similar cells in another (fig 1). They were present in all cells lining a few of the glands in each of the two specimens. The eosinophilic bodies were of different size and occupied the subnuclear aspect of the cytoplasm. The homogenous material seemed to have pushed the nucleus of these cells towards the free border of the cells. In other cells eosinophilic homogenous bodies in the supranuclear cytoplasmic area were also seen (fig 2). The cells differed from other types of pyloric cells reported in the gastric mucosa. ${ }^{5}$ A panel of histochemical reactions (periodic acid Schiff, alcian blue ( $\mathrm{pH} 2 \cdot 5$ ), high iron diamine, Congo red and the Grimelius silver technique) and immunohistochemical stainings (IgG, IgM, IgA, $\kappa, \lambda$, chromogranin $A$ and cystatin $C$ ) were all negative except for Cystatin C. This protein is a cystein proteinase inhibitor composed of 120 amino acid residues (molecular weight 13359) and is free from carbohydrates. $^{6}$

\section{Comment}

It has been shown by northern blot technique that Cystatin C mRNA is present in preparations from the stomach and small intestine which suggests that it is synthesised in these sites. $^{6}$ In a recent study the presence of Cystatin C in the normal epithelial cells of pyloric gastric glands and Brunner's glands was demonstrated using immunohistochemical techniques (Lignelid $\mathbf{H}$ and Jacobsson B, unpublished observations). Cystatin $\mathrm{C}$ is therefore probably synthesised by these cells in physiological conditions and the presently described eosinophilic inclusions, which were more strongly Cystatin C immunoreactive, probably represent intracytoplasmic accumulations of Cystatin C. Both patients were men, aged 59 and 67 years of age, respectively. The two specimens showed early adenocarcinoma of intestinal type. The cells with eosinophilic bodies were found while assessing the extent of intestinal metaplasia using morphometry ${ }^{7}$ in 33 gastrectomy specimens from Japanese nationals. Of interest was the fact that while $6.7 \%$ (or two of 33 ) of the gastrectomy specimens contained gastroduodenal mucous cells with eosinophilic bodies, none of more than 500 reviewed gastrectomies from European and North American patients demonstrated similar cells with eosinophilic inclusions.

The cells described here differ from the six types of vacuolated pyloric cells that have been 


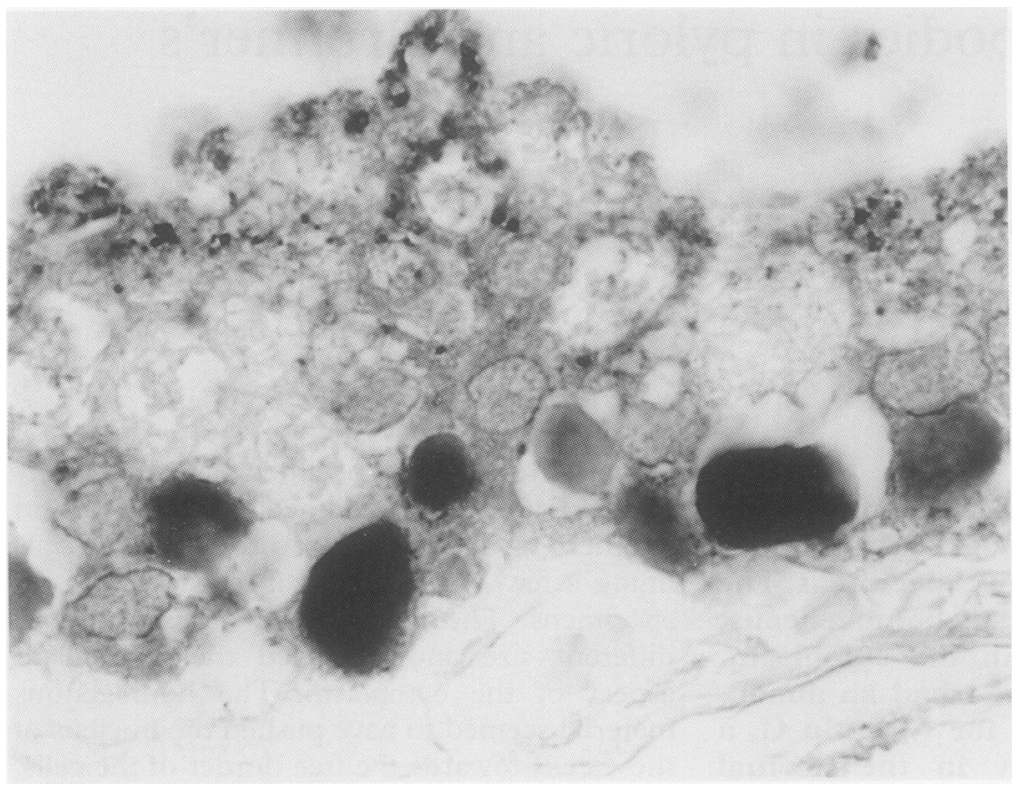

Figure 2 Strong positivity of the intracytoplasmic eosinophilic material following immunohistochemical staining with cystatin $C$.

reported before. ${ }^{8-10}$ Further studies are necessary to assess the true prevalance of mucous gastroduodenal cells with eosinophilic bodies in Japanese nationals and to clarify the functional importance of the Cystatin C material retained in these cells.

This study was supported by a grant of the Foundations of Promotions of Cancer Research, Tokyo, Japan, and by a grant of the Swedish Medical Research Council project 03X-0623.

1 Helander HF. The cells of the gastric mucosa. Int Rev Cytol 1981;70:217-89

2 Junqueira LC, Carneiro J. Digestive tract. In: Basic histology 4th ed. Los Angeles:Lange Medical, 1983:361-2.

3 Owen DA. Normal histology of the stomach. Am f Surg Pathol 1986;10:48-61

4 Rhodin JAG. The alimentary system. In: Histology: $A$ text and atlas. London: Oxford University Press 1974:544-51

5 Rubio CA. Five types of pyloric cells in the antral mucosa of the stomach. Path Res Pract 1992;188:157-61.

6 Abrahamson M, Olafsson I, Palsdottir A, et al. Structure and expression of the human cystatin $\mathrm{C}$ gene. Biochem $\mathcal{f}$ 1990;268:287-94.

7 Rubio CA, Hirota T, Itabashi M, Hirohashi S, Kato Y. Quantitation of gastric intestinal metaplasia by morphometry in Japanese patients. Jpn $\mathcal{f}$ Cancer Res 1992; metry in

8 Rubio CA, KatoY. Six types of intraepithelial vacuoles in the human gastric mucosa. Path Res Pract 1988;183 $321-25$

9 Rubio CA, Kato Y, Kitagawa T, Sugano H. A pitfall in the interpretation of intestinal metaplasia of the stomach Acta Pathol Microbiol Immunol Scand (A) 1986; 94:165-6.

10 Thompson IW, Day DW, Wright NA. Subnuclear vacuolated mucous cells: a novel abnormality of simple mucinecreting cells of non-specialised gastric mucosa and Brunner's glands. Histopathology 1987;11:1067-81.

\title{
Reassessment of the rate of fixative diffusion
}

\author{
R D Start, C M Layton, S S Cross, J H F Smith
}

Department of Histopathology, Nothern General Hospital, Sheffield

R D Start

C M Layton

S S Cross

J H F Smith

Correspondence to

University of Sheffield

Medical School, PO Box

596, Beech Hill Road,

Sheffield S10 2UL

Accepted for publication

3 June 1992
Dr Roger D Start,

Department of Pathology,

\begin{abstract}
The diffusion of fixatives is slow. Early work using plasma gels and animal tissues showed the distance penetrated by a fixative to be a simple function of the fixation time but this relation has not been established in human tissues. The rates of diffusion into whole human spleens were measured for three primary fixatives over periods ranging from one to 25 days. A positive correlation was demonstrated between penetration distance $(\mathrm{mm})$ and fixation time (hours). The diffusion rates were slower than those in previous studies. These results have possible implications for the handling of surgical specimens.
\end{abstract}

(f Clin Pathol 1992;45:1120-1121)

Diffusibility coefficients of fixatives

\begin{tabular}{lll}
\hline Fixative & $K^{\star}$ & $r$ (standard error) \\
\hline 4\% formaldehyde solution & $0.55(0.78)$ & $0.88(\mathrm{p}<0.001)$ \\
Saturated picric acid solution & $0.40(0.50)$ & $0.79(0.001<\mathrm{p}<0.01)$ \\
$5 \%$ acetic acid solution & $0.90(1.20)$ & $0.82(0.001<\mathrm{p}<0.01)$ \\
\hline
\end{tabular}

${ }^{\star}$ Figures in parentheses are the values of $\mathrm{K}$ from Medawar, $1941^{2}$
Tissues are usally fixed before microscopic examination and effective fixation is essential for accurate histological interpretation. Fixation depends not only on the rate at which a fixative reacts with tissue components, but also on the ability of the fixative to diffuse into tissues. An important rate limiting factor within the complex process of fixation is the slow speed of fixative diffusion into tissues.

Our understanding of this subject is largely based on early studies which examined the diffusion of fixatives into plasma gels and animal tissues. ${ }^{1-3}$ These studies indicated that fixatives obey the laws of diffusion and that the distance penetrated by a fixative depends on a simple function of fixation time. This distance in millimetres is equal to the square root of the fixation time in hours, multiplied by a coefficient of diffusibility $(K)$ for that fixative. ${ }^{23}$ More complicated formulae have been proposed, ${ }^{4}$ but no further studies have tested this relation nor examined the diffusion of fixatives into human tissues. This study was designed to examine the rate of fixative diffusion into a human tissue in the context of routine surgical specimens using necropsy material. 